\title{
Innovation technique eet lutte des classes
}

\section{Pierre-Philippe Rey}

\section{OpenEdition}

Journals

Édition électronique

URL : https://journals.openedition.org/tc/1031

DOI : $10.4000 /$ tc. 1031

ISSN : 1952-420X

\section{Éditeur}

Éditions de l'EHESS

\section{Édition imprimée}

Date de publication : 1 septembre 1983

ISSN : 0248-6016

\section{Référence électronique}

Pierre-Philippe Rey, « Innovation technique eet lutte des classes », Techniques \& Culture [En ligne], 2 | 1983, mis en ligne le 26 janvier 2006, consulté le 29 septembre 2022. URL : http:// journals.openedition.org/tc/1031; DOI : https://doi.org/10.4000/tc.1031

Ce document a été généré automatiquement le 29 septembre 2022.

Tous droits réservés 


\section{Innovation technique eet lutte des classes}

Pierre-Philippe Rey 